\title{
PERAMALAN TINGKAT SUKU BUNGA PASAR UANG ANTAR BANK (PUAB) DENGAN VECTOR AUTOREGRESSIVE EXOGENOUS (VARX)
}

\author{
C. R. Ferry ${ }^{\mathrm{i}} \operatorname{Irwan}^{\mathrm{ii}}$, Nurfadilahiii
}

\footnotetext{
${ }^{\text {i }}$ Mahasiswa Program Studi Matematika

ii Program Studi Matematika-UIN Alauddin

iii Program Studi Matematika-UIN Alauddin
}

terbagi dua yakni teknik peramalan kualitatif yang mengandalkan judgment serta intuisi manusia dibanding penggunaan data yang bersifat historis, dan teknik peramalan kuantitatif yang digunakan untuk data siklus atau musiman yang bersifat runtun waktu. Data runtun waktu merupakan data ang dikumpulkan berdasarkan urutan waktu. Biasanya dalam satuan menit, jam, hari, minggu, bulan atau tahun.

Ada beberapa metode yang biasa digunakan untuk peramalan salah satunya metode Vector Autoregressive Exogenous (VARX). Metode ini merupakan pengembangan dari metode Vector Autoregressive (VAR).

Berbeda dengan metode VAR, metode VARX mendefinisikan bahwa hanya ada dua peubah yang digunakan, yaitu endogen dan eksogen. Endogen berarti faktor yang mempengaruhi suatu sistem dari dalam, sedangkan eksogen mempengaruhi dari luar. VARX berupa metode analisis runtun waktu multivariat yang digunakan untuk menjelaskan perubahan data serta hubungan timbal balik antara variabel eksogen dan endogen.

Terdapat banyak penelitian yang menggunakan metode (VARX), seperti peramalan volume penjualan total sepeda motor di kab. Bojonegoro dan Lamongan menggunakan pendekatan ARIMAX dan VARX oleh Maghfirotul, Destri, dan Suhartono yang berkesimpulan bahwa jenis sepeda motor paling banyak terjual adalah jenis sepeda motor Automatic dengan penjualan tertinggi terjadi pada beberapa hari sebelum hari raya Idul Fitri, dan Bony Yudhistira meneliti pemodelan VARX terhadap variabel makroekonomi di Indonesia dengan hasil penelitian yang menunjukan bahwa nilai kurs rupiah terhadap dollar Amerika dipengaruhi oleh suku bunga Bank Indonesia dan inflasi di Amerika. 
VARX umumnya dipakai untuk meneliti kasus yang memiliki variabel endogen dan eksogen. Salah satu hal menarik untuk diteliti berkaitan kasus metode VARX yakni pada peramalan tingkat suku bunga pasar uang antar bank.

Pasar Uang Antar Bank (PUAB) berfungsi sebagai sarana untuk mempermudah masyarakat memperoleh dana-dana jangka pendek agar bisa membiayai modal kerja atau keperluan jangka pendek lainnya di lembaga perbankan. ${ }^{1}$

Berdasarkan penjelasan di atas, peneliti akan meramalkan tingkat suku bunga pasar uang antar bank menggunakan metode Vector Autoregressive Exogenous (VARX).

\section{TINJAUAN PUSTAKA}

\section{Peramalan}

Peramalan merupakan bagian integral dari kegiatan pengambilan keputusan, sebab efektif atau tidaknya suatu keputusan umumnya bergantung pada beberapa faktor yang tidak dapat dilihat pada waktu keputusan itu diambil. Peranan peramalan menjelajah kedalam banyak bidang seperti ekonomi, riset operasional, administrasi Negara,dan lain-lain. Peramalan merupakan suatu teknik untuk memperkirakan suatu nilai pada masa yang akan datang dengan memperhatikan data masa lalu maupun data pada masa kini.

\section{Deret Waktu}

Deret waktu (time series) merupakan serangkaian data pengamatan yang terjadi berdasarkan indeks waktu secara berurutan dengan interval waktu tetap. Analisis deret waktu adalah salah satu prosedur statistika yang diterapkan untuk meramalkan struktur-struktur probabilistik. Struktur dengan keadaan yang akan terjadi dimasa yang akan datang dalam rangka pengambilan keputusan.

\section{Autoregressive (AR)}

Salah satu pendekatan peramalan adalah pendekatan regresi, namun secara umum regresi

\footnotetext{
${ }^{1}$ Dyah Utami. Determinan Suku Bunga Pasar Uang Antar Bank di Indonesia, Jurnal, Vol.5, No.1 (Universitas Negeri Semarang, 2011), h.34

2 Aswi dan Sukarna. Analisis Deret Waktu Teori dan Aplikasi. (Makassar: Andira Publisher, 2006), hal.35
}

merupakan suatu metode yang berupaya meramalkan variasi suatu peubah dari sejumlah faktor lain yang disebut peubah bebas. Bentuk umum dari sebuah model regresi untuk $k$ peubah bebas yaitu

$$
Y=\beta_{0}+\beta_{1} X_{1}+\beta_{2} X_{2}+\cdots+\beta_{k} X_{k}+\varepsilon
$$

dimana $\varepsilon$ merupakan suatu peubah acak, parameter $\beta_{0}, \beta_{1}, \beta_{2}, \ldots, \beta_{k}$ adalah koefisienkoefisien regresi yang perlu ditaksir.

Model-model yang mungkin dihasilkan dari pengidentifikasian data deret waktu dapat berupa model autoregressive (AR), integrated (I), dan moving average (MA) atau kombinasi dari dua model (ARI, IMA, ARMA) atau kombinasi dari tiga komponen model (ARIMA), dengan beberapa persamaan tersebut didapatkan bentuk umum suatu proses autoregressive dengan orde $p$ adalah $Z_{t}=$ $\phi_{1} Z_{t-1}+\phi_{2} Z_{t-2}+\cdots+\phi_{p} Z_{t-p}+a_{t}{ }^{2}$

\section{Moving Average (MA)}

Perbedaan model moving average (MA) dengan model autoregressive (AR) terletak pada jenis peubah bebasnya. Pada model MA peubah bebasnya adalah nilai sisaan pada periode sebelumnya atau hubungan ketergantungan antara nilai-nilai galat yang berurutan. ${ }^{3}$

Berbeda dengan model AR model MA orde $q$ mempunyai bentuk umum sebagai berikut:

$$
Z_{t}=a_{t}-\theta_{1} a_{t-1}-\theta_{2} a_{t-2}-\cdots-\theta_{q} a_{t-q}
$$

\section{Differencing}

Proses pembedaan (differencing) bisa dilakukan apabila kondisi stasioner dalam rata-rata tidak terpenuhi. Proses differencing pada orde pertama merupakan selisih antara data ke-t dengan data ke $\mathrm{t}-1$, yaitu $\Delta Z_{t}=Z_{t}-Z_{t-1}$

Adapun bentuk differencing untuk orde kedua adalah

$$
\begin{aligned}
\Delta^{2} Z_{t}=\Delta Z_{t}- & \Delta Z_{t-1} \\
& =\left(Z_{t}-Z_{t-1}\right)-\left(Z_{t-1}-Z_{t-2}\right) \\
& =Z_{t}-2 Z_{t-1}+Z_{t-2}
\end{aligned}
$$

Dengan demikian bentuk umum differencing adalah $W_{t}=(1-\mathrm{B})^{\mathrm{d}} \mathrm{Z}_{\mathrm{t}}=\Delta^{\mathrm{d}} \mathrm{Z}_{\mathrm{t}}$

\footnotetext{
${ }^{3}$ Mutia Ramadhanti Haflil. Model State Space untuk Data Deret Waktu Peubah Tunggal, Skripsi (Bogor: Jurusan Statistika Fakultas Matematika dan Ilmu Pengetahuan Alam.Institut Pertanian Bogor, 2008), h.1
} 
dimana $\Delta^{\mathrm{d}} \mathrm{Z}_{\mathrm{t}}=\mathrm{Z}_{\mathrm{t}-\mathrm{d}}$

\section{Vector Autoregressive (VAR)}

Model VAR dalam aplikasinya lebih sederhana. Penggunaan banyak variabel endogen akan beresiko pada estimasinya. Skalar runtun waktu $Y_{t}$ dapat dituliskan dalam bentuk Autoregressive (AR) seperti berikut:

Atau dapat dituliskan sebagai

$$
Y_{t}=\alpha+\phi(B) Y_{t}+\varepsilon_{t}
$$

$Y_{t}=\alpha+\phi_{1} Y_{t-1}+\phi_{2} Y_{t-2}+\cdots+\phi_{p} Y_{t-p}+\varepsilon_{t}$ dengan:

$$
\begin{aligned}
& \mathrm{E}\left(\varepsilon_{t}\right)=0 \text { dan } \\
& \mathrm{E}\left(\varepsilon_{t}, \varepsilon_{s}\right)=\left\{\begin{array}{l}
\sigma^{2}, \text { untuk } t=s \\
0 \text { untuk yang lainnya }
\end{array}\right.
\end{aligned}
$$

kemudian dari persamaan diatas, vektor $\left(Y_{1 t}, Y_{2 t}, Y_{3 t}, \ldots, Y_{n t}\right)$ dapat ditulis sebagai $Y_{t}$

$\left(Y_{11_{t-1}}, Y_{12_{t-1}}, Y_{13_{t-1}}, \ldots, Y_{1 n_{t-1}}\right)$ sebagai $Y_{1 t-1}$

$\left(Y_{11_{t-2}}, Y_{12_{t-2}}, Y_{13_{t-2}}, \ldots, Y_{1 n_{t-2}}\right)$ sebagai $Y_{1 t-2}$

$\left(Y_{11_{t-p}}, Y_{12_{t-p}}, Y_{13_{t-p}}, \ldots, Y_{1 n_{t-p}}\right)$ sebagai $Y_{1 t-p}$ dan vektor $\phi_{1}, \phi_{2}, \phi_{3}, \ldots, \phi_{n}$ diestimasi dengan rumus regresi linear sederhana.

Dalam regresi terdapat perbedaan antara pengamatan $\left(y_{i}\right)$ dengan perkiraan $(Y)$ perbedaan dari beberapa nilai pengamatan dengan nilai perkiraan disebut simpangan.Simpangan menandakan adanya kesalahan (error) dalam hasil prakiraan. Setiap terjadi simpangan berarti terdapat error antara nilai-nilai $\left(y_{i}\right)$ dengan $(Y)$ maka berturut-turut adalah. ${ }^{4}$

$e=y_{1}, y_{2}, \ldots, y_{n}$ dan $\mathrm{Y}=\alpha+\beta \mathrm{X}$

Sehingga

$$
\begin{gathered}
e_{1}=y_{1}-Y_{1} \\
e_{2}=y_{2}-Y_{2} \\
\vdots \\
e_{n}=y_{n}-Y_{n}=\sum_{i=1}^{n} e_{i}=\sum\left(y_{i}-Y_{i}\right)
\end{gathered}
$$

dari sini dapat juga dituliskan sebagai

$Y_{t}=\alpha+\phi Y_{t-1}$

kemudian

$e_{1}{ }^{2}=\left(Y_{1}-Y_{1-1}\right)^{2}$

$e_{2}^{2}=\left(Y_{2}-Y_{2-1}\right)^{2}$

${ }^{4}$ Hadiyatullah. Model Vector Autoregression (VAR) dan Penerapannya untuk Anlisis Pengaruh Harga Migas terhadap Indeks Harga Konsumen (IHK), $\vdots$

$e_{i}^{2}=\left(Y_{t}-Y_{t-1}\right)^{2}=\sum_{i=1}^{n} e_{i}^{2}$

maka $\sum_{i=1}^{n} e_{i}^{2}=s=\sum\left(Y_{t}-\alpha-\phi Y_{t-1}\right)^{2}$

selanjutnya turunkan terhadap $\alpha \operatorname{dan} \phi \frac{\partial s}{\partial \alpha}=$ $\frac{\partial\left(\sum\left(Y_{t}-\alpha-\phi Y_{t-1}\right)^{2}\right)}{\partial \alpha}$

$=-2 \sum\left(Y_{t}-\alpha-\phi Y_{t-1}\right)=0$

$=\sum\left(Y_{t}-\alpha-\phi Y_{t-1}\right)=0$

$$
\begin{aligned}
& \frac{\partial s}{\partial \phi}=\frac{\partial\left(\sum\left(Y_{t}-\alpha-\phi Y_{t-1}\right)^{2}\right)}{\partial \phi} \\
& \quad=-2 \sum Y_{t-1}\left(Y_{t}-\alpha-\phi Y_{t-1}\right)=0 \\
& \quad=\sum Y_{t-1}\left(Y_{t}-\alpha-\phi Y_{t-1}\right)=0 \\
& \sum \alpha=\sum Y_{t}-\phi \sum Y_{t-1} \\
& \frac{n \alpha}{n}=\frac{\sum Y_{t}}{n}-\phi \frac{\sum Y_{t-1}}{n}
\end{aligned}
$$

dari sini dapat juga dituliskan sebagai

$\alpha=\frac{\sum Y_{t}}{n}-\phi \frac{\sum Y_{t-1}}{n}$

$$
\begin{gathered}
\sum Y_{t-1} Y_{t}-\sum Y_{t-1} \frac{\sum Y_{t}}{n}+\phi \frac{\left(\sum Y_{t-1}\right)^{2}}{n} \\
-\phi \sum Y_{t-1}{ }^{2}=0 \\
n \sum Y_{t-1} Y_{t}-\sum Y_{t-1} \sum Y_{t}+\phi\left(\sum Y_{t-1}\right)^{2} \\
-n \phi \sum Y_{t-1}{ }^{2}=0
\end{gathered}
$$

$\phi\left(\left(\sum Y_{t-1}\right)^{2}-n \sum Y_{t-1}^{2}\right)=-n \sum Y_{t-1} Y_{t}+$ $\sum Y_{t-1} \sum Y_{t}$

$$
\phi=\frac{-n \sum Y_{t-1} Y_{t}+\sum Y_{t-1} \sum Y_{t}}{\left(\sum Y_{t-1}\right)^{2}-n \sum Y_{t-1}{ }^{2}}
$$

$\widehat{\phi}=\frac{n \sum Y_{t-1} Y_{t}-\sum Y_{t-1} \sum Y_{t}}{n \sum Y_{t-1}{ }^{2}-\left(\sum Y_{t-1}\right)^{2}}$

Sedangkan vektor $\left(\alpha_{1}, \alpha_{2}, \alpha_{3}, \ldots, \alpha_{n}\right)$ sebagai $\alpha$ lalu $\alpha_{1}, \alpha_{2}, \alpha_{3}, \ldots, \alpha_{n}$ diestimasi dari

$$
\sum Y_{t}-\sum \alpha-\hat{\phi} \sum Y_{t-1}=0
$$

lalu dengan mensubsitusi $\hat{\phi}$ diperoleh

$$
\begin{gathered}
\sum Y_{t}-\left(\frac{n \sum Y_{t-1} Y_{t}-\sum Y_{t-1} \sum Y_{t}}{n \sum Y_{t-1}{ }^{2}-\left(\sum Y_{t-1}\right)^{2}}\right) \sum Y_{t-1}-\sum \alpha=0 \\
\frac{n\left(\sum Y_{t-1}{ }^{2} \sum Y_{t}-\sum Y_{t-1} Y_{t} \sum Y_{t}\right)}{n \sum Y_{t-1}{ }^{2}-\left(\sum Y_{t-1}\right)^{2}}=n \alpha \\
\frac{\sum Y_{t-1}{ }^{2} \sum Y_{t}-\sum Y_{t-1} Y_{t} \sum Y_{t}}{n \sum Y_{t-1}{ }^{2}-\left(\sum Y_{t-1}\right)^{2}}=\alpha \\
\hat{a}=\frac{\sum Y_{t-1}{ }^{2} \sum Y_{t}-\sum Y_{t-1} Y_{t} \sum Y_{t}}{n \sum Y_{t-1}{ }^{2}-\left(\sum Y_{t-1}\right)^{2}}
\end{gathered}
$$

Skripsi(Yogyakarta: Fakultas MIPA Universitas Negeri Yogyakarta, 2011), h.27 
Vector Autoregressive Exogenous (VARX)

Model Vector Autoregressive Exogenous (VARX) merupakan pengembangan dari model Vector Autoregressive (VAR) yang menggunakan variabel eksogen dalam sistem persamaanya. Variabel eksogen (variabel independen) pada VARX ditentukan diluar model dan bersifat mempengaruhi variabel endogen dalam suatu sistem persamaan.Sedangkan variabel endogen (variabel dependen) dalam VARX ditentukan di dalam model dan dapat dipengaruhi oleh variabel eksogen.

Adapun model struktural VARX didefinisikan dengan:

$$
\phi(B) Y_{t}=a+\theta(B) X_{t}+\varepsilon_{t}
$$

\section{Kausalitas Granger}

Kausalitas Granger merupakan salah satu langkah untuk mengetahui hubungan antara variabel satu dengan variabel yang lain. Misalkan ada dua variabel $\mathrm{X}$ dan $\mathrm{Y}$ maka ada beberapa kemungkinan yang bisa terjadi, diantaranya:

a. X menyebabkan Y

b. Y menyebabkan $\mathrm{X}$

c. X menyebabkan Ydan Y menyebabkan X

d. $X$ dan Y tidak memiliki hubungan. ${ }^{5}$

\section{Pasar Uang Antar Bank (PUAB)}

Pasar uang (money market) merupakan pasar yang menyediakan sarana pengalokasian dan pinjaman dana jangka pendek. Dana jangka pendek adalah dana-dana yang dihimpun dari perusahaan ataupun perorangan dengan batasan waktu sampai satu tahun yang dapat diperjualbelikan dalam pasar uang. Perwujudan dari pasar semacam ini berupa institusi dimana individu atau organisasi yang mempunyai kelebihan dana jangka pendek bertemu dengan individu yang memerlukan dana.

Pasar uang memiliki fungsi sebagai sarana alternatif bagi lembaga-lembaga keuangan, perusahaan non-keuangan dan peserta-peserta lainnya, baik dalam memenuhi kebutuhan jangka pendek maupun meminjamkan data atas kelebihan. Pasar uang secara tidak langsung juga sebagai sarana pengendali moneter yang

5 _. Pemodelan Pergerakan Indeks Harga Saham Gabungan (IHSG) dan laju inflasi di Indonesia dilakukan oleh penguasa moneter dalam operasi pasar terbuka. Pelaksanaan operasi pasar terbuka dilakukan oleh Bank Indonesia dengan menggunakan Sertifikat Bank Indonesia (SBI) atau suku bunga Bank Indonesia (BI Rate), dan Surat Berharga Pasar Uang (SBPU). BI Rate digunakan agar suku bunga kebijakan moneter dapat secara cepat memengaruhi pasar uang, perbankan dan sektor riil, sedangkan SBPU berfungsi menambah jumlah uang yang beredar. Sistem perekonomian membutuhkan banyak sarana untuk bisa beradaptasi seperti PUAB. Pasar uang antar bank atau sering disebut inter bank call money market merupakan salah satu sarana penting untuk mendorong pengembangan pasar uang.

Adapun beberapa faktor yang mempengaruhi tingkat suku bunga PUAB antara lain seperti Singapore Interbank Offered Rate (SIBOR) dan suku bunga Bank Indonesia (BI Rate). SIBOR adalah suku bunga rata-rata bank di Singapura yang ditetapkan berdasarkan suku bunga yang ditawarkan oleh 8 bank terkemuka di Singapura.SIBOR menjadi salah satu acuan jika Bank Indonesia membutuhkan Dollar untuk keperluan tertentu. Sedangkan BI Rate akan dinaikkan apabila inflasi ke depan diperkirakan melampaui sasaran yang telah ditetapkan, sebaliknya BI Rate akan diturunkan apabila inflasi ke depan diperkirakan berada di bawah sasaran yang telah ditetapkan.

Mekanisme pasar uang ini dapat dilaksanakan melalui proses kliring dan diluar proses kliring. Kliring artinya penyelesaian utang piutang antar bank-bank, yang biasanya berbentuk surat-surat berharga.

\section{PUAB melalui kliring}

Berikut syarat-syarat dalam melakukan tranksaksi melalui kliring

a. .Bank yang meminjam berkewajiban untuk mnyerahkan nota kredit kepada peserta yang dipinjam.

b. Bank yang menerima pinjaman menerbitkan surat sanggup yangditujukan kepada bank pemberi pinjaman sesuai kesepakatan oleh pihak yang bersangkutan.

menggunakan metode VARX, Skripsi (Perpustakaan Universitas Pendidikan Indonesia Bandung), h.39 
c. Bank yang meminjam berkewajiban untuk mencantumkan jumlah transaksi pada bil saldo kliring sebagai komponen dana pasar uang yang diserahkan

\section{PUAB diluar proses kliring}

Berikut syarat-syarat dalam melakukan tranksaksi diluar kliring

a. Bank yang menerima pinjaman menerbitkan surat sanggup yang ditujukan kepada bank pemberi pinjaman sesuai kesepakatan oleh pihak yang bersangkutan.

b. Menyampaikan tembusan surat sanggup yang bersangkutan kepada Bank Indonesia.

c. Pencairan kembali surat sanggup dilakukan dengan cara penerbitan nota debit oleh peserta yang memberikan pinjaman. ${ }^{6}$

\section{METODOLOGI PENELITIAN}

Langkah-langkah yang dilakukan dalam rangka mencapai tujuan penelitian adalah sebagai berikut :

1. Plot data untuk mengecek kestasioneran data dalam rata-rata, jika belum maka dilakukan differencing

2. Melakukan uji Kausalitas Granger untuk mengetahui hubungan antara variabel satu dengan variabel yang lainnya.

3. Penentuan Lag Optimum untuk membatasi lag optimal pada model.

4. Penentuan orde menggunakan Akaike's Information Criterion (AIC) untuk menghasilkan model terbaik.

5. Melakukan uji normal multivariat pada residual data untuk mengetahui data berdistribusi normal atau tidak, jika data tidak berdistribusi normal maka dilakukan transformasi.

6. Melakukan uji white noise pada model yang terpilih.

7. Melakukan peramalan (forecasting).

\section{HASIL}

\section{Deskriptif data}

Data penelitian diperoleh dari website Bank Indonesia www.bi.go.id dan merupakan data bulanan mulai dari Januari 2012 s/d Desember 2016.

Tabel 4.1 Data Suku Bunga PUAB tahun 2012 s /d 2016

\begin{tabular}{|c|c|c|c|c|}
\hline \multicolumn{5}{|c|}{ Tahun } \\
\hline $\mathbf{2 0 1 2}$ & $\mathbf{2 0 1 3}$ & $\mathbf{2 0 1 4}$ & $\mathbf{2 0 1 5}$ & $\mathbf{2 0 1 6}$ \\
\hline 0.0449 & 0.0622 & 0.0593 & 0.0766 & 0.06 \\
\hline 0.0426 & 0.0622 & 0.0576 & 0.0571 & 0.061 \\
\hline 0.0427 & 0.0627 & 0.0652 & 0.0523 & 0.043 \\
\hline 0.043 & 0.0624 & 0.0586 & 0.0508 & 0.043 \\
\hline 0.0429 & 0.0622 & 0.0568 & 0.0514 & 0.045 \\
\hline 0.0429 & 0.0619 & 0.0575 & 0.051 & 0.045 \\
\hline 0.0459 & 0.0669 & 0.0568 & 0.0535 & 0.045 \\
\hline 0.0519 & 0.0598 & 0.0589 & 0.0485 & 0.053 \\
\hline 0.057 & 0.0591 & 0.0796 & 0.0519 & 0.046 \\
\hline 0.0583 & 0.0586 & 0.0618 & 0.0546 & 0.042 \\
\hline 0.0617 & 0.0585 & 0.0605 & 0.0443 & 0.04 \\
\hline 0.0655 & 0.0632 & 0.0766 & 0.0427 & 0.04 \\
\hline
\end{tabular}

Tabel 4.2 Data BI Rate tahun 2012 s/d 2016

\begin{tabular}{|c|c|c|c|c|}
\hline \multicolumn{5}{|c|}{ Tahun } \\
\hline $\mathbf{2 0 1 2}$ & $\mathbf{2 0 1 3}$ & $\mathbf{2 0 1 4}$ & $\mathbf{2 0 1 5}$ & $\mathbf{2 0 1 6}$ \\
\hline 0.06 & 0.0575 & 0.075 & 0.0775 & 0.0775 \\
\hline 0.0575 & 0.0575 & 0.075 & 0.075 & 0.07 \\
\hline 0.0575 & 0.0575 & 0.075 & 0.075 & 0.0675 \\
\hline 0.0575 & 0.0575 & 0.075 & 0.075 & 0.055 \\
\hline 0.0575 & 0.0575 & 0.075 & 0.075 & 0.055 \\
\hline 0.0575 & 0.06 & 0.075 & 0.075 & 0.0525 \\
\hline 0.0575 & 0.065 & 0.075 & 0.075 & 0.0525 \\
\hline 0.0575 & 0.07 & 0.075 & 0.075 & 0.0525 \\
\hline 0.0575 & 0.0725 & 0.075 & 0.075 & 0.05 \\
\hline 0.0575 & 0.0725 & 0.075 & 0.075 & 0.0475 \\
\hline 0.0575 & 0.075 & 0.0775 & 0.075 & 0.0475 \\
\hline
\end{tabular}

\footnotetext{
${ }^{6}$ Any Widyatsari. Pasar Uang Antar Bank Syariah, Jurnal, Vol. 4, No. 2(Fakultas Ekonomi Universitas Riau, 2014) h.15-16.
} 
Tabel 4.3 Data SIBOR tahun 2012 s/d 2016

\begin{tabular}{|c|c|c|c|c|}
\hline \multicolumn{5}{|c|}{ Tahun } \\
\hline $\mathbf{2 0 1 2}$ & $\mathbf{2 0 1 3}$ & $\mathbf{2 0 1 4}$ & $\mathbf{2 0 1 5}$ & $\mathbf{2 0 1 6}$ \\
\hline 0.0079 & 0.0058 & 0.0058 & 0.0058 & 0.0058 \\
\hline 0.0075 & 0.0058 & 0.0058 & 0.0058 & 0.0058 \\
\hline 0.0073 & 0.0058 & 0.0058 & 0.0058 & 0.0058 \\
\hline 0.0071 & 0.0058 & 0.0058 & 0.0058 & 0.0058 \\
\hline 0.0069 & 0.0058 & 0.0058 & 0.0058 & 0.0058 \\
\hline 0.007 & 0.0058 & 0.0058 & 0.0058 & 0.0058 \\
\hline 0.0067 & 0.0058 & 0.0058 & 0.0058 & 0.0058 \\
\hline 0.0067 & 0.0058 & 0.0058 & 0.0058 & 0.0058 \\
\hline 0.0063 & 0.0058 & 0.0058 & 0.0058 & 0.0058 \\
\hline 0.0061 & 0.0058 & 0.0058 & 0.0058 & 0.0058 \\
\hline 0.0058 & 0.0058 & 0.0058 & 0.0058 & 0.0058 \\
\hline 0.0058 & 0.0058 & 0.0058 & 0.0058 & 0.0058 \\
\hline
\end{tabular}

Plot Data Penelitian

a. Suku Bunga PUAB sebelum di differencin $g$

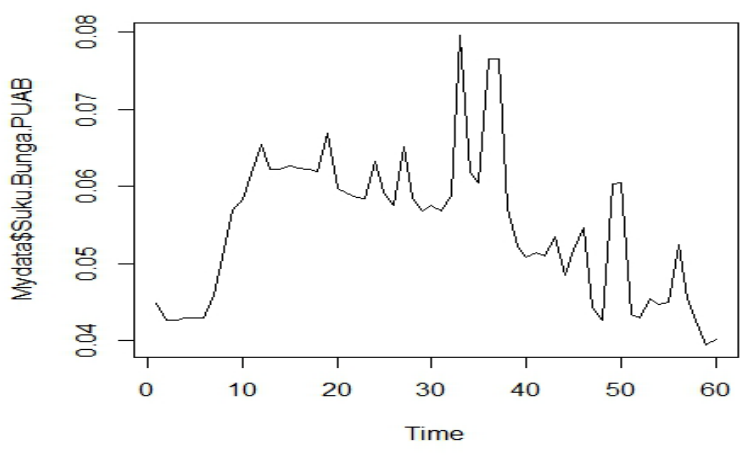

Gambar 4.1 Plot data suku bunga PUAB seb elum di differencing.

b. suku Bunga PUAB setelah di $d$ ifferencing

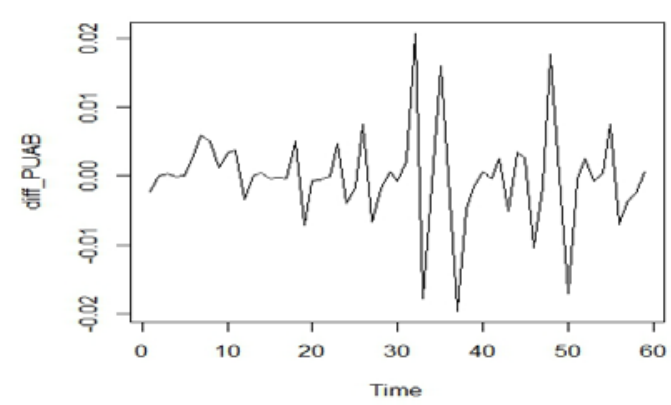

Gambar 4.2 Plot data suku bunga PUAB sete lah di differencing. c. BI Rate sebelum di differencing

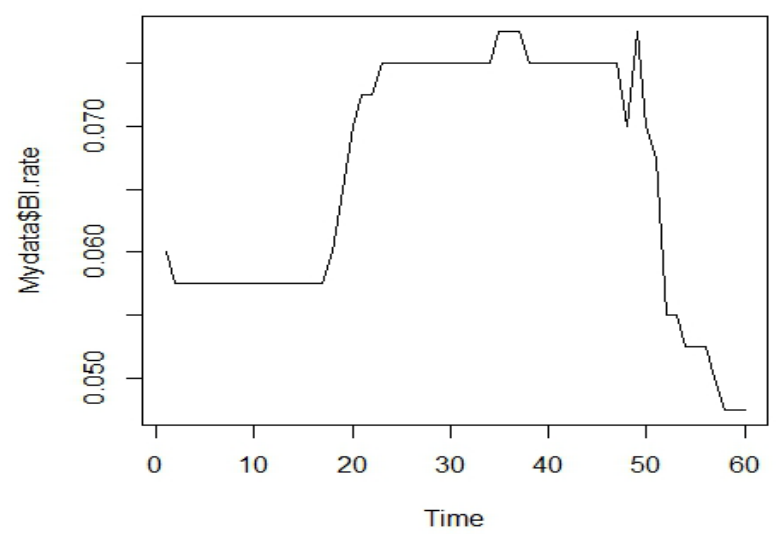

Gambar 4.3 Plot data BI rate sebelum di diff erencing.

d. BI Rate setelah di differencing

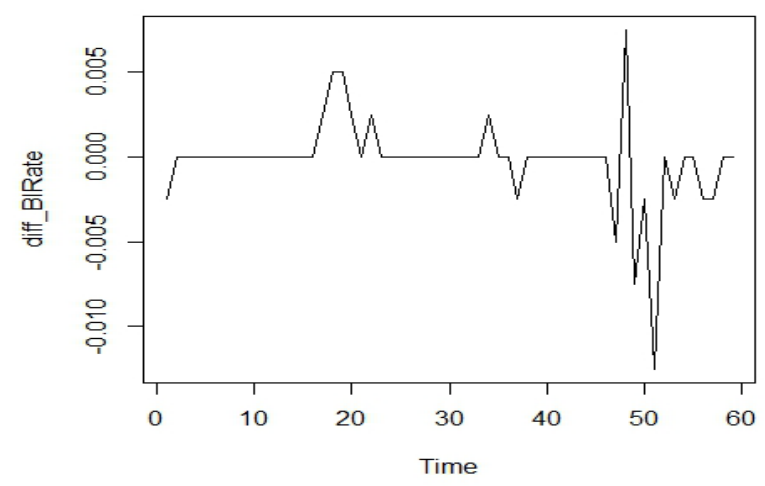

Gambar 4.4 Plot data BI rate setelah di differencing.

BI Rate setelah di differencing kedua

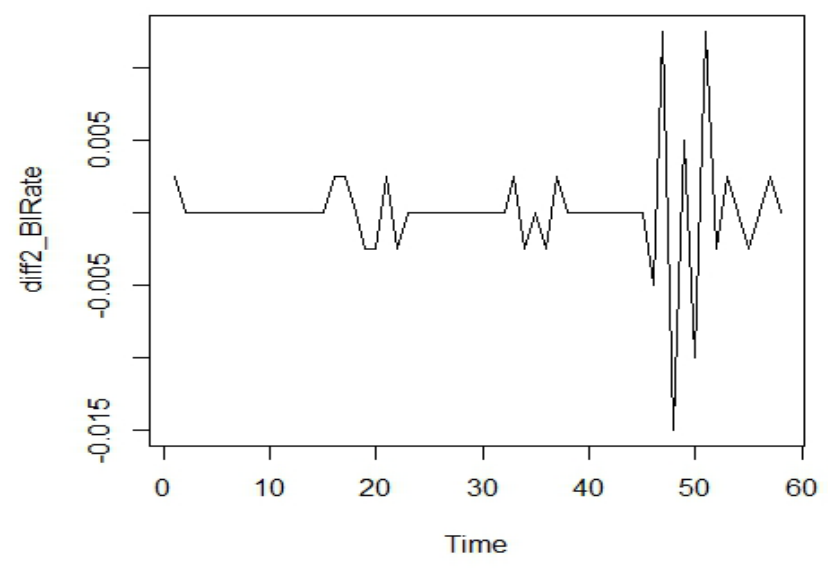

Gambar 4.5 Plot data BI rate setelah di differencing kedua.

e. SIBOR 


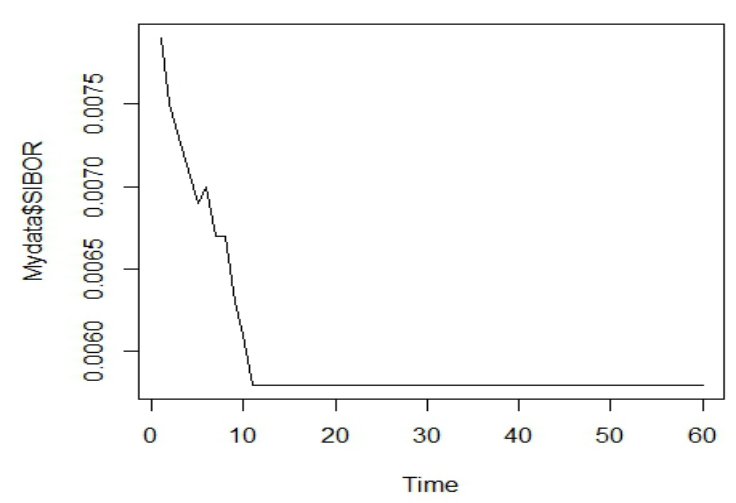

Gambar 4.6 Plot data SIBOR

\section{Uji Kausalitas Granger}

a. Suku Bunga PUAB

Diperoleh nilai probabilitas sebesar 0.72 $49>\alpha$ sebesar 0.05 dimana $H_{0}$ dinyatak an diterima, sehingga dapat disimpulkan bahwa variabel Suku Bunga PUAB (diff _PUAB), bukan penyebab granger BIrate dan Sibor.

b. BI rate

Diperoleh nilai probabilitas sebesar 0.39 $83>\alpha$ sebesar 0.05 dimana $H_{0}$ dinyatak an diterima, sehingga dapat disimpulkan bahwa variabel BI rate (diff2_Birate), bu kan penyebab granger Suku Bunga PUA $B$ dan Sibor.

c. SIBOR

Diperoleh nilai probabilitas sebesar 0.79 $12>\alpha$ sebesar 0.05 dimana $H_{0}$ dinyatak an diterima, sehingga dapat disimpulkan bahwa variabel SIBOR (SIBOR), bukan penyebab granger Suku Bunga PUAB da n BIrate.

\section{Lag Optimum}

Berdasarkan Tabel 4.4 nilai Akaike Information Criterion (AIC) terkecil terdapat pada Lag ke-3, sebesar -21.9535 sehingga model dibatasi denga n panjang Lag optimum, yakni 3.

\section{Perkiraan Model Terbaik}

a. $\operatorname{VARX}(1,1)$

Pada model VARX $(1,1)$ dimana orde vari abel endogen $=1$ dan orde variabel eksog en $=1$, memiliki nilai Akaike Information Criterion (AIC) sebesar -21.78557
Tabel 4.4 Daftar perkiraan Lag optimum bese rta nilai AIC

\begin{tabular}{|c|c|}
\hline Lag & Nilai AIC \\
\hline 0 & -20.97 \\
\hline 1 & -21.715 \\
\hline 2 & -21.951 \\
\hline 3 & -21.954 \\
\hline 4 & -21.927 \\
\hline 5 & -21.819 \\
\hline 6 & -21.747 \\
\hline 7 & -21.756 \\
\hline 8 & -21.627 \\
\hline 9 & -21.625 \\
\hline 10 & -21.598 \\
\hline
\end{tabular}

b. $\operatorname{VARX}(1,2)$

Pada model VARX $(1,2)$ dimana orde vari abel endogen $=1$ dan orde variabel eksog en $=2$, memiliki nilai Akaike Information Criterion (AIC) sebesar -21.69658

c. $\operatorname{VARX}(1,3)$

Pada model VARX $(1,3)$ dimana orde vari abel endogen $=1$ dan orde variabel eksog en $=3$, memiliki nilai Akaike Information Criterion (AIC) sebesar -21.60804

d. $\operatorname{VARX}(2,1)$

Pada model VARX $(2,1)$ dimana orde vari abel endogen $=2$ dan orde variabel eksog en $=1$, memiliki nilai Akaike Information Criterion (AIC) sebesar -21.97008

e. $\operatorname{VARX}(2,2)$

Pada model VARX $(2,2)$ dimana orde vari abel endogen $=2$ dan orde variabel eksog en $=2$, memiliki nilai Akaike Information Criterion (AIC) sebesar -21.93811

f. $\operatorname{VARX}(2,3)$

Pada model VARX $(2,3)$ dimana orde vari abel endogen $=2$ dan orde variabel eksog en $=3$, memiliki nilai Akaike Information Criterion (AIC) sebesar -21.85043

g. $\operatorname{VARX}(3,1)$

Pada model VARX $(3,1)$ dimana orde vari abel endogen $=3$ dan orde variabel eksog en $=1$, memiliki nilai Akaike Information Criterion (AIC) sebesar -21.93282

h. $\operatorname{VARX}(3,2)$ 
Pada model VARX $(3,2)$ dimana orde vari abel endogen $=3$ dan orde variabel eksog en $=2$, memiliki nilai Akaike Information Criterion (AIC) sebesar -21.91293

i. $\operatorname{VARX}(3,3)$

Pada model VARX $(3,3)$ dimana orde vari abel endogen $=3$ dan orde variabel eksog en $=3$, memiliki nilai Akaike Information Criterion (AIC) sebesar -21.85344

\section{Penerapan Model}

Berdasarkan nilai AIC yang diperoleh masingmasing model pada Tabel 4.5 maka nilai AIC terkecil terdapat pada model VARX $(2,1)$ sebesar -21.97008 model inilah yang terpilih untuk diestimasi.

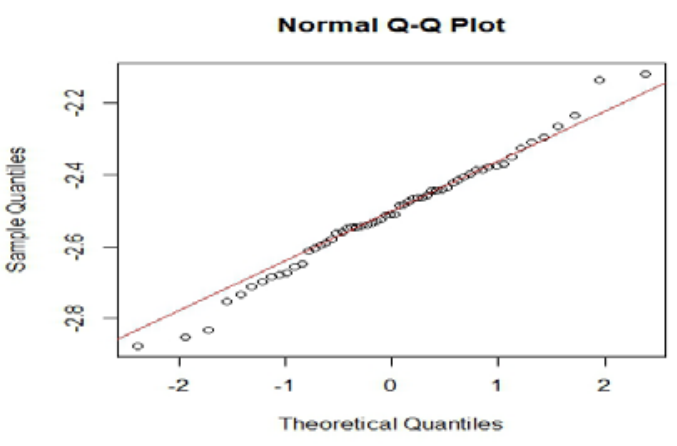

Gambar 4.7 Plot normal residual PUAB

Berdasarkan hasil analisis, estimasi persamaan untuk model VARX $(2,1)$ adalah

$$
\begin{aligned}
& {\left[\begin{array}{c}
\Delta \text { puab }_{t} \\
\text { birate }_{t}
\end{array}\right]=\left[\begin{array}{ll}
14.560 & 1.681
\end{array}\right]\left[\begin{array}{l}
\Delta \text { sibor }_{t-1} \\
\Delta \text { sibor }_{t-1}
\end{array}\right]+} \\
& {\left[\begin{array}{cc}
-0.257 & 0.375 \\
-0.047 & -0.675 \\
-0.512 & 0.208 \\
-0.135 & 0.074
\end{array}\right]\left[\begin{array}{c}
\Delta \text { puab }_{t-1} \\
\Delta \text { birate }_{t-1}
\end{array}\right]}
\end{aligned}
$$

\section{Uji Normal Multivariat Residual}

Setelah diperoleh model VARX dan dilihat pengaruh antar ke 3 variabel, selanjutnya pengujian pada residual endogen yakni suku bunga PUAB dan BI rate.

Berdasarkan hasil analisis sebelumnya data residual variabel suku bunga PUAB dan BI rate tidak berdistribusi normal multivariat, sehingga perlu di transformasi.

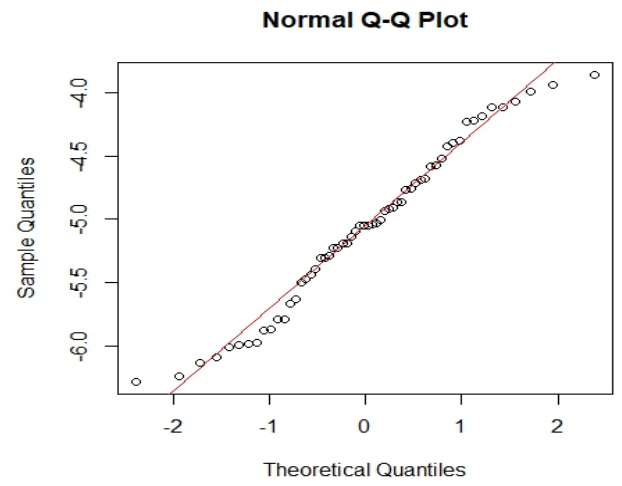

Gambar 4.8 Plot normal residual BI rate

Setelah di transformasi selanjutnya dibuktikan d engan plot pada Gambar 4.7 dan Gambar 4.8. Ga mbar 4.7 menunjukkan bahwa residual data PUA $B$ berpola linear atau berada disekitar garis lurus , begitu juga pada Gambar 4.8 yang menunjukka $\mathrm{n}$ bahwa data residual BI Rate berpola linear ata u berada disekitar garis lurus.

\section{Uji Asumsi White Noise}

Berdasarkan hasil analisis pada Lampiran 5 variabel endogen suku bunga $\mathrm{PUAB}$ dan $\mathrm{BI}$ rate pada model VARX $(2,1)$ memenuhi asumsi white noise, dengan nilai $p$ - value masing-masing sebesar 0.44 dan $0.24>\alpha$ sebesar 0.05

\section{Peramalan}

Berdasarkan hasil analisis pada Lampiran 7, peramalan nilai suku bunga PUAB mulai bulan Januari 2017 s/d Desember 2018 sebagai ditunjukkan pada table 4.5.

\section{PEMBAHASAN}

Berdasarkan analisis data yang telah dilakukan, uji kestasioneritas data atau uji Augmented Dicky Fuller (ADF) dengan Hipotesis sebagai berikut :

$$
\begin{aligned}
& H_{0} \text { : Data tidak stasioner } \\
& H_{1} \text { : Data telah stasioner }
\end{aligned}
$$

Pengambilan keputusan : jika $p$-value $>$ $\alpha$ maka $H_{0}$ diterima, dan data dinyatakan tidak stasioner.

Pada Gambar 4.2, Gambar 4.5, dan Gambar 4.6 terlihat plot data sudah stasioner. Selanjutnya untuk memperkuat dugaan, dilakukan uji ADF pada masing-masing variabel, nilai p-value pada variabel suku bunga PUAB yang telah di differencing sebesar 0.01 , variabel $\mathrm{BI}$ rate yang 
telah di differencing sebesar 0.01, dan variabel SIBOR sebesar 0.024 .

Tabel 4.5 Hasil Peramalan

\begin{tabular}{|c|c|c|}
\hline No. & Waktu & Hasil Ramalan \\
\hline 1 & Jan-17 & 0.01669 \\
\hline 2 & Feb-17 & 0.02947 \\
\hline 3 & Mar-17 & 0.03509 \\
\hline 4 & Apr-17 & 0.03933 \\
\hline 5 & May-17 & 0.04276 \\
\hline 6 & Jun-17 & 0.04155 \\
\hline 7 & Jul-17 & 0.04605 \\
\hline 8 & Aug-17 & 0.04564 \\
\hline 9 & Sep-17 & 0.05092 \\
\hline 10 & Oct-17 & 0.05266 \\
\hline 11 & Nov-17 & 0.05583 \\
\hline 12 & Dec-17 & 0.0547 \\
\hline 13 & Jan-18 & 0.05412 \\
\hline 14 & Feb-18 & 0.05377 \\
\hline 15 & Mar-18 & 0.05354 \\
\hline 16 & Apr-18 & 0.0534 \\
\hline 17 & May-18 & 0.05331 \\
\hline 18 & Jun-18 & 0.05326 \\
\hline 19 & Jul-18 & 0.05323 \\
\hline 20 & Aug-18 & 0.05322 \\
\hline 21 & Sep-18 & 0.05322 \\
\hline 22 & Oct-18 & 0.05323 \\
\hline 23 & Nov-18 & 0.05324 \\
\hline 24 & Dec-18 & 0.05325 \\
\hline
\end{tabular}

Nilai uji ADF pada masing-masing variabel bernilai $<\alpha$ sebesar 0.05 dimana $H_{0}$ dinyatakan ditolak sehingga dapat disimpulkan bahwa data sudah stasioner.

Kemudian dari persamaan yang telah diperoleh dapat diketahui bahwa variabel eksogen SIBOR pada Lag-1 atau periode 1 bulan sebelumnya dapat mempengaruhi nilai suku bunga PUAB serta $\mathrm{BI}$ rate masing-masing sebesar 14.560 dan 1.681 sedangkan pada Lag-2 atau periode 2 bulan sebelumnya dapat mempengaruhi masingmasing sebesar -14.560 dan -1.681. Setiap satuan variabel nilai suku bunga PUAB juga dipengaruhi oleh nilai suku bunga PUAB itu sendiri pada 1 bulan sebelumnya dan 2 bulan sebelumnya masing-masing sebesar -0.769 dan 0.769 serta dipengaruhi oleh variabel endogen lainnya yakni BI rate pada periode 1 bulan sebelumnya dan 2 bulan sebelumnya masingmasing sebesar 0.583 dan -0.583 .

Sedangkan untuk setiap satuan variabel nilai BI rate juga dipengaruhi oleh nilai BI rate itu sendiri pada 1 bulan sebelumnya dan 2 bulan sebelumnya masing-masing sebesar -0.601 dan 0.601 serta dipengaruhi oleh variabel endogen lainnya yakni suku bunga PUAB pada periode 1 bulan sebelumnya dan 2 bulan sebelumnya masing-masing sebesar -0.182 dan 0.182 .

Untuk uji normal multivariat residual diperoleh n ilai p-value masing-masing sebesar $0.1998133 \mathrm{~d}$ an 0.1710708 ini menunjukkan bahwa p-value d ari keduanya $>\alpha$ sebesar 0.05 , dengan demikian $H_{0}$ dinyatakan ditolak yang berarti data residual berdistribusi normal multivariat.

Hipotesis :

\section{$H_{0}$ : Data tidak berdistribusi normal multivariat}

$H_{1}$ : Data berdistribusi normal multivariat Pengambilan keputusan : jika $p-$ value $<\alpha$ m aka $H_{0}$ diterima, dan disimpulkan bahwa data tid ak berdistribusi normal multivariat.

\section{KESIMPULAN}

Dari hasil analisis diperoleh kesimpulan bahwa, data suku bunga PUAB, BI Rate, dan SIBOR diasumsikan kedalam model yang terpilih. Berdasarkan nilai AIC terkecil diperoleh model VARX(2,1). Pengujian normal multivariat pada error residual menyatakan data berdistribusi normal multivariat.

\section{DAFTAR PUSTAKA}

[1] Arsyad, Lincoln. Peramalan Bisnis Edisi Pertama. Yogyakarta: BPFE

[2] Departemen Agama RI. Al-Qur'an Terjemahannya dan Asbabun Nuzul. Surakarta: PT. Indiva Media Kreasi, 2009

[3] Djuraidah A., Saputro, D.R.S., dkk. Model Additive-Vector Autoregressive Exogenous untuk prediksi curah hujan di Kabupaten Indramayu, Jurnal, Vol.15, No.2 (Bogor: Institut Pertanian Bogor, 2013)

[4] Jumroh. Estimasi Maksimum Likelihood Pada ARIMA $(1,1,0)$ BOX JENKINS, Skripsi (Semarang: Fakultas MIPA Universitas Negeri Semarang, 2005) 
[5] Hadiyatulah. Model VectorAutoregressive (VAR) dan Untuk Analisis Harga Migas Terhadap Indeks Harga Konsumen (IHK), Skripsi (Yogyakarta: Fakultas MIPA Universitas Negeri Yogyakarta, 2011)

[6] Haflil, Mutia Ramadhani. Model State Space Untuk Data Deret Waktu Peubah Tunggal, Skripsi (Bogor: Fakultas Matematika dan Ilmu Pengetahuan Alam Institut Pertanian Bogor, 2008)

[7] M.Quraish Shihab. Tafsir Al Mishbah:Pesan, Kesan dan Keserasian Al-Qur'an. Jakarta: Lentera Hati, 2003

[8] Novi, Amanita. (Universitas Negeri Yogyakarta) Nugraha, Bony Yudhistira. Pemodelan Vector Autoregressive $X$ TerhadapVariabel Makroekonomi di Indonesia, Skripsi (Jurusan Matematika Universitas Diponegoro Semarang)

[9] _. Pemodelan Pergerakan Indeks Harga Saham Gabungan (IHSG) dan Laju Inflasi di Indonesia Menggunakan Metode VARX, Skripsi (Perpustakaan UniversitasPendidikan Indonesia Bandung)

[10] Salamah, Mutia dkk. TIME SERIES ANALYSIS, Buku Ajar (Surabaya: Fakultas MIPA Institut Teknologi Sepuluh Nopember, 2003)

[11] Sukarna dan Aswi. Analisis Deret Waktu Teori dan Aplikasi. Makassar: Andira Publisher, 2006.

[12] Utami, Dyah. Determinan Suku Bunga Pasar Uang Antar Bank di Indonesia, Jurnal, Vol.5, No.1 (Universitas Negeri Semarang, 2011)

[13] Widyatsari, Any. Pasar Uang Antar Bank Syariah, Jurnal, Vol. 4, No.2 (Fakultas Ekonomi Universitas Riau, 2014) 